\section{Bovine Pulp Tissue Dissolution Ability of Irrigants Associated or Not to Ultrasonic Agitation}

\author{
Renata Senger Niewierowski ${ }^{1}$, Luíza Rodrigues Scalzilli ${ }^{1}$, Renata Dornelles \\ Morgental ${ }^{2}$, José Antônio Poli de Figueiredo ${ }^{1}$, Fabiana Vieira Vier-Pelisser ${ }^{1}$, \\ Maristela Gutierrez de Borba ${ }^{1}$, Alexandre Corrêa Ghisi ${ }^{1}$
}

\author{
'Clinical Department, Dental School, \\ PUCRS - Pontifícia Universidade \\ Católica do Rio Grande do Sul, \\ Porto Alegre, RS, Brazil \\ ${ }^{2}$ Department of Semiology and Clinics, \\ Dental School, UFPel - Universidade \\ Federal de Pelotas, Pelotas, RS, Brazil
}

Correspondence: Renata Dornelles Morgental, Rua Gonçalves Chaves, 457, 96015-560 Pelotas, RS, Brasil. Tel: +55-53-3222-4439. E-mail: remorgental@hotmail.com
The aim of this study was to evaluate the tissue dissolution ability of different irrigating solutions associated or not to ultrasonic agitation. Ninety bovine pulp fragments $(n=10$ per group) were weighed and then placed individually in Eppendorf test tubes containing the following irrigants: $\mathrm{G} 1-2.5 \%$ sodium hypochlorite $(\mathrm{NaOCl}) ; \mathrm{G} 2-2.5 \% \mathrm{NaOCl}+$ ultrasonic agitation (US); G3- 2.5\% NaOCl + 0.2\% cetrimide (CTR); G4- 2.5\% NaOCl + $0.2 \%$ CTR + US; G5- 400 ppm Sterilox (SX); G6- SX + US; G7- 0.2\% CTR; G8- 0.2\% CTR + US; G9- saline solution. Two blinded observers assessed the samples continuously for the first $4 \mathrm{~h}$, and then every hour for the next $12 \mathrm{~h}$. Dissolution speed was calculated by dividing the initial pulp weight $(\mathrm{mg})$ by the period of time until complete dissolution (min). Data were compared by ANOVA and Tukey post hoc test with a 5\% significance level. G1 to G4 dissolved pulp fragments completely and G2 was significantly faster than the other groups. G5 to G9 did not exhibit dissolving activity. In conclusion, only groups containing $\mathrm{NaOCl}$ were capable of pulp tissue dissolution, which was enhanced by ultrasonic agitation, but did not alter when $0.2 \%$ cetrimide was associated. This isolated solution and Sterilox showed no dissolving capacity, regardless the use of ultrasound.
Key Words: sodium hypochlorite, pulp dissolution, irrigants, cetrimide, Sterilox, ultrasound, super-oxidized water.

\section{Introduction}

Success in endodontic therapy depends directly on chemomechanical debridement of the root canal system, which includes the removal of pulp remnants, dentin chips and microorganisms. Potentially contaminated organic and inorganic debris may remain in areas where endodontic instruments cannot act. Thus, root canal irrigation becomes imperative (1).

An endodontic irrigating solution must have four main properties: antimicrobial activity, water solubility, low toxicity to periradicular tissues and tissue dissolution ability (2). Sodium hypochlorite $(\mathrm{NaOCl})$ is the most commonly used root canal irrigant, since it is able to kill a wide range of pathogens and dissolve pulp tissue $(1,2)$.

Tissue dissolution ability of $\mathrm{NaOCl}$ depends on its concentration, volume, $\mathrm{pH}$, agitation, temperature and also on the contact time with the pulp tissue (3). It has been shown that $\mathrm{NaOCl}$ solutions with higher concentration dissolve more easily vital and necrotic remnants of pulp, but at the same time, increase the risk of damage to the periradicular tissues and oral mucosa $(2,3)$.

An effective way to clean the root canal system is the agitation of the irrigating solution. Therefore, ultrasound associated with sodium hypochlorite is a useful adjunct for cleaning difficult anatomical areas (4). The vibration produced by the ultrasound devices provides a continuous flow of irrigating solution in the root canal, facilitating the removal of debris and increasing the temperature of the irrigant (5), which may improve its dissolving properties (3).

Another approach to improve the action of irrigants and its penetration into non-instrumented areas of the root canal system is to reduce the surface tension. This can be achieved by heat or chemical surfactants (6). The addition of surfactants to $\mathrm{NaOCl}$ has been investigated over the years. Some studies report increased tissue dissolution with the combination of $\mathrm{NaOCl}$ and a surfactant agent $(3,7)$. However, other studies have not shown this advantage $(8,9)$.

Cetrimide is an example of cationic detergent that has antimicrobial activity and is capable of lowering the mechanical stability of bacterial biofilms (10). It has been used in combination with various irrigating solutions ( $\mathrm{NaOCl}$, chlorhexidine, EDTA, etc.) to reduce surface tension and increase the penetration in the root canal system $(8,11)$.

Due to limitations of $\mathrm{NaOCl}$, especially in relation to toxicity, the use of irrigants known as "electrochemically activated water" $(12,13)$, "oxidative potential water" (14) or "super-oxidized water" $(15,16)$ has been suggested in the literature. Despite different denominations, they are all oxidizing solutions containing hypochlorous acid and produced according to the same principles, i.e., by passing a saline solution over titanium-coated electrodes. These solutions have been assessed for their ability to remove 
debris and smear layer from root canals $(13,14)$ and eliminate bacteria $(12,15)$. Studies have found favorable results and biocompatibility with vital tissues (14).

Considering the aforementioned, it is appropriate to conduct a study to assess the tissue dissolution ability provided by $\mathrm{NaOCl}$, cetrimide and Sterilox, an electrochemically activated water, associated or not with ultrasonic agitation.

\section{Material and Methods}

Ninety pulp fragments from 45 bovine incisors were used in this study. The animals were slaughtered for commercial reasons and this study had no influence on the animals' fate. Teeth were stored frozen and then left overnight at room temperature $\left(23 \pm 2{ }^{\circ} \mathrm{C}\right)$ for defrosting.

Endodontic access was made on the lingual surface of teeth using a round diamond bur (\#1014; KG Sorensen, Cotia, SP, Brazil) at high speed and under refrigeration. Next, pulps were detached from the root canal walls with a straight probe (SS White, Rio de Janeiro, RJ, Brazil) and removed with dental tweezers (EDLO, Canoas, RS, Brazil). The pulps were measured with a millimeter ruler (EDLO) and cut with scalpel blade, creating two 10-mm fragments each.

Pulp fragments were weighed on a precision scale (SP Labor, Presidente Prudente, SP, Brazil) and it was stipulated that each one should weigh approximately $0.006 \mathrm{mg}$ (weights ranged from $0.0061 \mathrm{mg}$ to $0.0069 \mathrm{mg}$ ). The pulp fragments were assigned to 9 groups $(n=10)$ and placed individually in Eppendorf test tubes containing $1 \mathrm{~mL}$ of their respective irrigating solutions. The groups were as follows: $\mathrm{G} 1-2.5 \%$ sodium hypochlorite ( $\mathrm{NaOCl}$ ); $\mathrm{G} 2-2.5 \%$ $\mathrm{NaOCl}+$ ultrasonic agitation (US); G3- $2.5 \% \mathrm{NaOCl}+0.2 \%$ Cetrimide (CTR) (1:1); G4- 2.5\% NaOCl + 0.2\% CTR (1:1) + US; G5- 400 ppm Sterilox (SX); G6- SX + US; G7- CTR; G8- CTR + US; G9- saline solution.

$\mathrm{NaOCl}$ solutions were prepared and the concentration was tested by iodometric titration (Cientec, Porto Alegre, $\mathrm{RS}$, Brazil) seven days prior to use and stored in the dark at room temperature. Cetrimide was prepared at the time of use by diluting the powder in distilled water. The $400 \mathrm{ppm}$ Sterilox solution (Optident Dental, Ilkley, West Yorkshire, UK) was also obtained just before use by a double passage of a sodium chloride solution (Optident Sterilox Electrolyte Solution, Optident Dental) by titanium electrodes, using the Sterilox Dental System (Optident Dental).

For groups with ultrasonic agitation, the NAC Plus device (Adiel, Ribeirão Preto, SP, Brazil) was used. Agitation was performed with size \#25 ultrasonic files (Adiel), activated for 3 cycles 20 s each. The file was immersed in the solution approximately $10 \mathrm{~mm}$ deep, away from the tissue specimens, without touching them.

The test tubes were visually assessed by two observers blinded to the experimental groups. The samples were continuously observed for the first $4 \mathrm{~h}$, and then every hour for the next $12 \mathrm{~h}$. The time for complete fragment dissolution was recorded in minutes. The dissolution speed was calculated by dividing pulp weight $(\mathrm{mg})$ by dissolution time (mg/min).

The data were tested for normality using the ShapiroWilk test. Normal distribution was detected for the "dissolution speed" variable. Groups were compared using ANOVA, followed by post-hoc Tukey test. Statistical analysis was performed with the BioEstat 5.0 software (CNPq, Brasília, DF, Brazil) at 5\% significance level.

\section{Results}

Results are presented in Figure 1. Only groups containing $\mathrm{NaOCl}(\mathrm{G} 1-\mathrm{G} 4)$ were capable of tissue dissolution, and were included in the statistical analysis. This study showed no tissue-dissolving activity for $0.2 \%$ CTR, SX, or saline (G5G9), regardless of ultrasonic agitation.

Tissue dissolution was significantly faster when $\mathrm{NaOCl}$ was combined with ultrasonic agitation $(p<0.05)$, but not altered by the association with CTR ( $p>0.05)$ or CTR and ultrasonic agitation $(p>0.05)$.

\section{Discussion}

Sodium hypochlorite is used worldwide as the main endodontic irrigant, in concentrations ranging from $0.5 \%$ to $6 \%$ due to its antimicrobial and tissue-dissolving properties (2). An increase in $\mathrm{NaOCl}$ concentration may facilitate pulp tissue dissolution (3), but at the same time, it increases the cytotoxic effect $(2,17)$. This fact motivated the present study, which aimed to compare the ability of different solutions associated or not with ultrasonic agitation, for dissolving pulp tissue and thus, an attempt to find an alternative to high concentration $\mathrm{NaOCl}$ in order to reduce the risks in clinical practice.

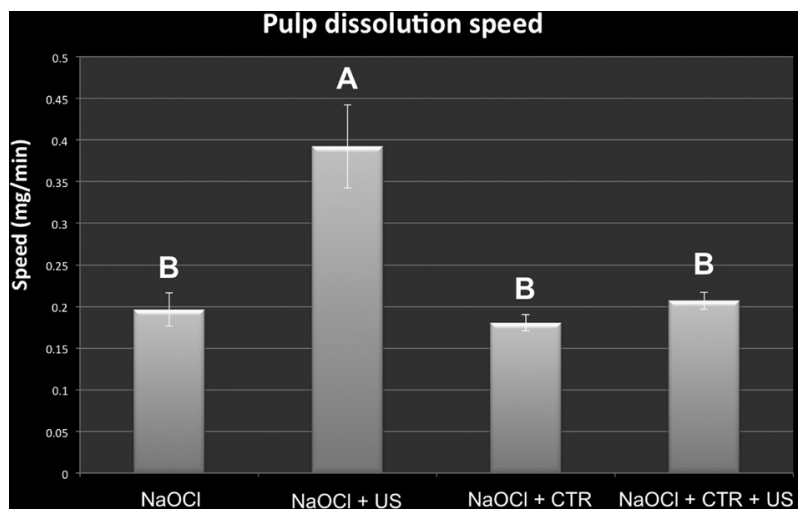

Figure 1. Mean dissolution speed $(\mathrm{mg} / \mathrm{mL})$ within the $\mathrm{NaOCl}$ groups. Different letters indicate statistically significant difference $(p<0.05)$. 
Due to limitations in obtaining human teeth for research, experiments were performed with pulp tissue from bovine teeth, since their characteristics are comparable to those of human pulp tissue, despite some minor differences (18). Furthermore, bovine pulps have been used to test tissue dissolution capacity of several endodontic irrigants $(11,19,20)$.

The current results agree with previous studies where only $\mathrm{NaOCl}$ solutions produced tissue dissolution $(20,21)$. It was demonstrated that $2.5 \% \mathrm{NaOCl}$ took, on average, 33 min to completely dissolve the pulp fragment with a $0.19 \mathrm{mg} / \mathrm{min}$ speed. When it was associated with ultrasonic agitation, the average dissolution time decreased to 16 $\mathrm{min}$, increasing the speed to $0.39 \mathrm{mg} / \mathrm{min}$. The present results agree with those of Stojicic et al. (3) and this effect is attributed to acoustic streaming and cavitation mechanisms. Ultrasonic activation of $\mathrm{NaOCl}$ has been advocated because it is claimed to accelerate chemical reactions and promote superior cleaning action $(4,22)$.

Cetrimide has been used in combination with different irrigating solutions to reduce surface tension and increase penetration in the root canal system (6). De Almeida et al. (11) reported that the time of bovine pulp dissolution was reduced when $\mathrm{NaOCl}$ was associated with cetrimide. However, in this study, there was no significant difference in dissolution time when these two irrigants were associated. The average dissolution time was $36 \mathrm{~min}$ with a speed of 0.18 $\mathrm{mg} / \mathrm{min}$, similar to $\mathrm{NaOCl}$ alone. These results agree with the findings of Clarkson et al. (8) and De-Deus et al. (23), which did not observe faster dissolution when combining $\mathrm{NaOCl}$ with a surfactant. It is important to notice that the rate used in this study was 1:1 diluted $\mathrm{NaOCl}$ and different rates deserve to be further investigated.

Rossi-Fedele et al. (20) evaluated the bovine pulp dissolution capacity of Aquatine Alpha Electrolyte (Sterilox ${ }^{\circledR}$ 200 ppm, pH 5.0), HealOzone and $2.5 \% \mathrm{NaOCl}$ when used alone or in association. The researchers reported tissuedissolving effects in all groups containing $\mathrm{NaOCl}$, while Sterilox was not effective. In the present study, pulp dissolution capacity was not encountered for Sterilox in higher concentration (400 ppm), which is a disadvantage compared to $\mathrm{NaOCl}$.

Comparing the tissue dissolution capacity of $\mathrm{NaOCl}$ and Sterilox, should be taken into account the differences in solvent concentration. $\mathrm{NaOCl}$ solution has high dissolution constant (mainly dissociated hypochlorite ions), while Sterilox has very low dissolution constant (larger proportion of hypochlorous acid). Therefore, tissue dissolution may depend on the amount of hypochlorite ions rather than the available free chlorine (20).

Considering the aforementioned, it may be speculated that the association of $2.5 \% \mathrm{NaOCl}$ with ultrasonic agitation is a clinical alternative to improve the debridement of the root canal system, minimizing the known side effects of highly concentrated $\mathrm{NaOCl}$, such as tissue toxicity and possible loss of dentin mechanical strength (24). However, these findings should be confirmed by further research.

Considering the current results and the limitations of this in vitro research, sodium hypochlorite remains as the best irrigating solution when it comes to tissue-dissolving ability and its association with ultrasonic agitation promotes faster pulp tissue dissolution. Cetrimide alone has no tissue-dissolving capacity and, when associated with $\mathrm{NaOCl}$, does not improve its action, regardless of the ultrasound. Sterilox also lacks dissolving ability, even when activated by ultrasound.

\section{Resumo}

0 objetivo deste estudo foi avaliar a capacidade de dissolução tecidual de diferentes soluções irrigadoras associadas ou não à agitação ultrassônica. Noventa fragmentos de polpa bovina ( $n=10$ por grupo) foram pesados e em seguida colocados individualmente em tubos tipo Eppendorf contendo os seguintes irrigantes: $\mathrm{G} 1$ - hipoclorito de sódio $(\mathrm{NaOCl})$ a 2,5\%; $\mathrm{G} 2-\mathrm{NaOCl}$ a 2,5\% + agitação ultrassônica (US); G3- NaOCl a 2,5\% + cetramida (CTR) a 0,2\%; G4- NaOCl a 2,5\% + CTR a 0,2\% + US; G5- 400 ppm Sterilox (SX); G6- SX + US; G7- CTR a 0,2\%; G8- CTR a 0,2\% + US; G9- solução salina. Dois observadores cegados em relação aos grupos experimentais avaliaram as amostras continuamente durante as primeiras $4 \mathrm{~h}$ e depois a cada hora pelas próximas $12 \mathrm{~h}$. A velocidade de dissolução foi calculada dividindo o peso inicial da polpa $(\mathrm{mg})$ pelo periodo de tempo até sua dissolução completa (min). Os dados foram comparados por ANOVA e teste post hoc de Tukey com nivel de significância de $5 \%$. Os grupos G1 a G4 dissolveram os fragmentos de polpa completamente e $\mathrm{G} 2$ foi significativamente mais rápido do que os outros. Os grupos G5 a G9 não apresentaram atividade de dissolução. Em conclusão, apenas grupos contendo $\mathrm{NaOCl}$ foram capazes de dissolver tecido pulpar, o que foi melhorado pela agitação ultrassônica, mas não alterado quando CTR a 0,2\% foi associada. Esta solução isolada e o Sterilox não mostraram nenhuma capacidade de dissolução, independentemente da utilização do ultrassom.

\section{References}

1. Zehnder M. Root canal irrigants. J Endod 2006;32:389-398.

2. Mohammadi Z. Sodium hypochlorite in endodontics: an update review. Int Dent J 2008;58:329-341.

3. Stojicic S, Zivkovic S, Qian W, Zhang H, Haapasalo M. Tissue dissolution by sodium hypochlorite: effect of concentration, temperature, agitation, and surfactant. J Endod 2010;36:1558-1562.

4. van der Sluis LW, Versluis M, Wu MK, Wesselink PR. Passive ultrasonic irrigation of the root canal: a review of the literature. Int Endod J 2007:40:415-426.

5. Ferreira RB, Marchesan MA, Silva-Sousa YT, Sousa-Neto M. Effectiveness of root canal debris removal using passive ultrasound irrigation with chlorhexidine digluconate or sodium hypochlorite individually or in combination as irrigants. J Contemp Dent Pract 2008;9:68-75.

6. Palazzi F, Morra M, Mohammadi Z, Grandini S, Giardino L. Comparison of the surface tension of $5.25 \%$ sodium hypochlorite solution with three new sodium hypochlorite-based endodontic irrigants. Int Endod J 2012;45:129-135.

7. Clarkson RM, Moule AJ, Podlich H, Kellaway R, Macfarlane R, Lewis $D$, et al.. Dissolution of porcine incisor pulps in sodium hypochlorite solutions of varying compositions and concentrations. Aust Dent J 2006;51:245-251.

8. Clarkson RM, Kidd B, Evans GE, Moule AJ. The effect of surfactant on the dissolution of porcine pulpal tissue by sodium hypochlorite 
solutions. J Endod 2012:38:1257-1260.

9. Rossi-Fedele G, Prichard JW, Steier L, Figueiredo JA. The effect of surface tension reduction on the clinical performance of sodium hypochlorite in endodontics. Int Endod J 2013;46:492-498.

10. Baca P, Junco P, Arias-Moliz MT, Castillo F, Rodriguez-Archilla A, FerrerLuque CM. Antimicrobial substantivity over time of chlorhexidine and cetrimide. J Endod 2012;38:927-930.

11. Almeida LH, Leonardo NG, Gomes AP, Giardino L, Souza EM, Pappen FG. Pulp tissue dissolution capacity of sodium hypochlorite combined with cetrimide and polypropylene glycol. Braz Dent J 2013;24:477-481.

12. Gulabivala K, Stock CJ, Lewsey JD, Ghori S, Ng YL, Spratt DA. Effectiveness of electrochemically activated water as an irrigant in an infected tooth model. Int Endod J 2004;37:624-631.

13. Marais JT. Cleaning efficacy of a new root canal irrigation solution: a preliminary evaluation. Int Endod J 2000;33:320-325.

14. Serper A, Calt S, Dogan AL, Guc D, Ozcelik B, Kuraner T. Comparison of the cytotoxic effects and smear layer removing capacity of oxidative potential water, $\mathrm{NaOCl}$ and EDTA. J Oral Sci 2001;43:233-238.

15. Rossi-Fedele G, Figueiredo JA, Steier L, Canullo L, Steier G, Roberts AP. Evaluation of the antimicrobial effect of super-oxidized water (Sterilox ${ }^{\circledR}$ ) and sodium hypochlorite against Enterococcus faecalis in a bovine root canal model. J Appl Oral Sci 2010;18:498-502.

16. Ghisi AC, Kopper PM, Baldasso FE, Sturmer CP, Rossi-Fedele G, Steier $L$, et al.. Effect of super-oxidized water, sodium hypochlorite and EDTA on dentin microhardness. Braz Dent J 2014;25:420-424.

17. Clarkson RM, Moule AJ. Sodium hypochlorite and its use as an endodontic irrigant. Aust Dent J 1998;43:250-256.
18. Koskinen KP, Stenvall H, Uitto VJ. Dissolution of bovine pulp tissue by endodontic solutions. Scand J Dent Res 1980;88:406-411.

19. Rossi-Fedele G, De Figueiredo JA. Use of a bottle warmer to increase $4 \%$ sodium hypochlorite tissue dissolution ability on bovine pulp. Aust Endod J 2008;34:39-42.

20. Rossi-Fedele G, Steier L, Dogramaci EJ, Canullo L, Steier G, de Figueiredo JA. Bovine pulp tissue dissolution ability of HealOzone ${ }^{\circledR}$, Aquatine Alpha Electrolyte ${ }^{\circledR}$ and sodium hypochlorite. Aust Endod J 2013;39:5761.

21. Naenni N, Thoma K, Zehnder M. Soft tissue dissolution capacity of currently used and potential endodontic irrigants. J Endod 2004;30:785-787.

22. Al-Jadaa A, Paque F, Attin T, Zehnder M. Necrotic pulp tissue dissolution by passive ultrasonic irrigation in simulated accessory canals: impact of canal location and angulation. Int Endod J 2009;42:59-65.

23. De-Deus G, de Berredo Pinho MA, Reis C, Fidel S, Souza E, Zehnder M. Sodium hypochlorite with reduced surface tension does not improve in situ pulp tissue dissolution. J Endod 2013;39:1039-1043.

24. Pascon FM, Kantovitz KR, Sacramento PA, Nobre-dos-Santos M, Puppin-Rontani RM. Effect of sodium hypochlorite on dentine mechanical properties. A review. J Dent 2009;37:903-908.

Received April 25, 2015 Accepted July 14, 2015 